\title{
Review of Janek Wasserman's The Marginal Revolutionaries: How Austrian Economists Fought the War of Ideas. New Haven, CT: Yale University Press, 2019, 354 pp.
}

\author{
OLA INNSET
}

National Library of Norway

The starting point for Janek Wasserman's new group history of the Austrian School of Economics is the appearance of Friedrich Hayek's The Road to Serfdom ([1944] 2007) at the top of Amazon's bestseller list in June 2010. The spike in sales for Hayek's anti-collectivist tract, some sixty-six years after its original publication, was due to the radical-right TV personality, Glenn Beck, who devoted an hour-long episode of his Fox News program to the book. The attention from Beck coincided with the Tea Party movement, the fallout of the 2008 financial crash, and the rise to fame of Republican politicians like Ted Cruz, Paul Ryan, and Ron Paulthe latter of which exclaimed, "we are all Austrians now", after winning the Republican presidential caucus in Iowa in 2012.

Wasserman's first publication was the acclaimed 2014 monograph Black Vienna: The Radical Right in the Red City, 1918-1938. Thus, he is in a privileged position to connect the current resurgence of the far-right in the USA and a school of economic thought originating in the Habsburg Empire of nineteenth-century Central Europe. In particular, Wasserman's ability to turn the loose and variated history of 'Austrianism' in both Austria and beyond into a cohesive narrative is impressive. It presents the idea of the 'Austrian School' without losing nuance or missing internal disagreements and other contingencies which punctuate its unique history. The Austrian School includes thinkers and characters as diverse as Friedrich von Wieser, Ludwig von Mises, Joseph Schumpeter, Oskar Morgenstern, Friedrich von Hayek, and Murray Rothbard. Wasserman does a great job at showing the reader both the differences and the many instances of common ground between them all.

The first four of the seven chapters are set in Vienna, and we learn about what Wasserman calls "The Prehistory and Early Years of the Austrian School” (roughly 1870-1890), "The Golden Age” (1890-1918), "Austria's End" (1918-early 1930s), and "Depression, Emigration, and Fascism" 
(the war years up until 1945). These chapters give a dense and ultimately satisfying account of the creation and development of an Austrian School of Economics. At the outset, the Austrian School was characterized by the development of marginal utility and Carl Menger's scornful attacks on the German Historical School. The famous Methodenstreit is given a rather sparse retelling, which perhaps leaves something to be desired for those seeking new insights on this seminal controversy about the relationship between theory and empiricism in economics. This could also be said of Wasserman's later retelling of both stages of the Socialist Calculation Debates, which are brief and not very novel. In this way, this book does not appear to be directed towards experts on these controversies or even to specialists on the history of economic thought. Rather it is written to uncover the meaning and context of the Austrian School for those who aren't already well-versed in intellectual debates over how to interpret this tradition-a category which includes the vast majority of academic economists, historians, and of course, the wider public.

Wasserman's retelling of the birth of the Austrian School and its role in Austria for some sixty years serves the primary function of contextualizing a school of thought which has recently popped up among far-right activists and politicians both in the USA and in Europe. References to both Hayek and Mises have been frequent in these circles for some time, in part due to the influence of various institutes and think tanks established in both their names. In the first chapters of the book, Wasserman delivers lively portraits of these bright, upper-class men and their involvements in imperial politics during the liberal golden age of the Habsburg Empire. He then moves on to post-empire Austria and the next generation's organizing of private seminars and research institutes financed by the Rockefeller Foundation, accompanied by drinking songs in the coffee houses and restaurants of the Ringstrasse. All of this is perhaps covered even better in, for instance, Erwin Dekker's The Viennese Students of Civilization (2016). But Wasserman's account is in many ways a set-up for what happens next: the intriguing story about what transpired when the events of World War II saw these people transplanted to the entirely different context of post-war USA.

In some ways, Wasserman's story is one of progressive radicalization from the 1870s up to the present moment. Socialists, Marxists, and other leftists were always antagonists for the Austrians, and even Carl Menger's spats with the German Historicists touched upon the subject of the role of the state in the economy. Eugen von Böhm-Bawerk was the School's 
leading light after Menger and produced one of the earliest and most serious critiques of Marx's Capital, the 1898 volume Karl Marx and the Close of His System (Böhm-Bawerk [1896] 1949). Yet, early Austrians like BöhmBawerk accepted both Marxists and other socialists in their seminars, which included Austro-Marxists like Otto Neurath and Rudolf Hilferding, and even the Russian Bolshevik Nikolai Bukharin. Early members of the Austrian School were not averse to social policies, and someone like Friedrich von Wieser also displayed sympathies for social democracy. Disagreements with socialists on friendly terms appear to have ended with Mises, who made his fame as a critic of socialism in the 1920s. Wasserman claims that Mises already had a more dogmatic approach in Vienna, and that he refused to admit those who did not share his political views into his seminar.

After arriving in the USA during the war, Austrians like Hayek, Schumpeter, Morgenstern, Fritz Machlup, and Gottfried Haberler were more immediately successful than Mises. Like Quinn Slobodian in Globalists (2018), Wasserman highlights the stories of Machlup and Haberler, who are less famous than Hayek and Mises today, but who were arguably more influential: Haberler, within the new institutional structure of international trade policy around the General Agreement on Trade and Tariffs (GATT), and Machlup, as the leader of the Bellagio group, who advised the influential Group of 30 (G30) during the build-up to the end of the Bretton Woods agreement.

All the Austrians were hugely successful in securing positions and patronages in their new circumstances, something that was often belied in their own self-presentation as outcasts and misunderstood geniusesstories of which have then been repeated by sympathetically inclined biographers. The conventional narrative of the Austrian economist being 'in the wilderness' post-emigration is thoroughly debunked by Wasserman, who writes:

When they were not presiding over the American Economic Association (AEA), the Econometric Society, the International Economics Association (IEA), or National Bureau of Economic Research (NBER), the US government called on their expertise, candidates from conservative parties in the United States and United Kingdom sought their advice, and the International Monetary Fund (IMF), the General Agreement on Tariffs and Trade (GATT), and the World Bank solicited their opinions on trade and monetary matters. (235) 
On top of this came the lavish funding from business interests sympathetic to the Austrians' anti-left politics. This was especially the case with Mises, who was on a yearly honorarium from the National Association of Manufacturers (NAM) as a consultant, was paid a stipend from Leonard Reed of the Foundation for Economic Education, and had his salary as a visiting professor at NYU covered by private contributions. Younger Austrians in exile, like Haberler, Machlup, Morgenstern, and indeed even Hayek, tended to see Mises' laissez-faire views as outdated, and his whole approach to economics and politics as highly dogmatic. However true, that was perhaps also what became Mises' attraction in his new country. Like Mises, Hayek moved away from pure economics and became more of a political philosopher, also engaging in activism through the Mont Pèlerin Society and the various think tanks and foundations that grew out of it. Nonetheless, Hayek's somewhat more nuanced views, and the bestowal of the 1974 Bank of Sweden prize upon him, made him into less of a fringe figure than Mises.

The latter's ideological fervor and lack of mainstream recognition instead led to the development of a 'heterodox' school of American economists devoted to Mises' ideas. This group ended up diverging in significant ways from the more diverse group of actual Austrians who had taken part in Mises' seminars in Vienna. A telling anecdote told by Wasserman relates to a planned birthday celebration for Mises, in which his Austrian and American friends and followers disagreed markedly on who ought to be invited.

Another angle on this important aspect of the story is given through Wasserman's dive into Fritz Machlup's attempt in the early 1980s of writing the history of the Austrian School. Drafts of Machlup's paper were shared with other Austrians, all of whom found it difficult to know who to include in the School. Machlup ended up making a distinction between 'Austrians', like himself, Hayek and Mises, who had been in Vienna and contributed to the development of the School; those he called 'un-Austrian Austrians', a category referring to people like Morgenstern and Schumpeter who were clearly from the Austrian School but who nonetheless departed from some of the teachings and followed diverging intellectual paths; and lastly, 'non-Austrian Austrians', a label designating the group of Americans worshipping at the altar of Mises. The various splits within this faction are covered well by Wasserman towards the end of the book. The most enduring split is perhaps that between overt racists and far-right activists building on Murray Rothbard's legacy in various Ludwig 
von Mises Institutes, and scholars connected to the Koch-funded Mercatus Institute at George Mason University, who took a hermeneutic turn, and ended up proposing a revamped Hayekianism (Boettke 2018).

One part of this mosaic, which is somewhat missing, is the so-called Virginia School of Constitutional Economics. James M. Buchanan and colleagues are certainly mentioned here and there; but the way in which this school specifically builds on Austrian ideas is not given much attention. Perhaps this is what gets lost in Wasserman's contention that Austrian economics eventually came to signify the sect built around Mises in the USA, and its various splits and off-shoots. All in all, Wasserman's masterful book paints a much needed critical yet scholarly picture of the Austrian School. His book is not a polemic against the Austrians; but unlike many of the accounts written by people personally connected to the School, he brings attention to these thinkers' privileged backgrounds and lifestyles, their fundamentally elitist politics, and the important connections to wealthy benefactors with clear political agendas. The last part of the book focuses on disagreements between far-right 'Austrians' and their more centrist counterparts, both in the USA and in Europe. Splits and conflicts have indeed taken place, also in Europe, where a large portion of the members of the German Hayek Institut recently ceded from the organization in protest to the close ties of some members to the far-right political party Alternative für Deutschland. Wasserman has therefore succeeded in demonstrating that the contested legacy of the Austrian School bears direct relevance to an understanding of modern politics.

\section{REFERENCES}

Boettke, Peter J. 2018. F. A. Hayek: Economics, Political Economy and Social Philosophy. London: Palgrave Macmillan.

Böhm-Bawerk, Eugen von. (1896) 1949. "Karl Marx and the Close of His System." In Karl Marx and the Close of His System by Eugen von Böhm-Bawerk and Böhm-Bawerk's Criticism of Marx by Rudolf Hilferding, edited by Paul M. Sweezy, 1-118. New York, NY: Augustus M. Kelley.

Dekker, Erwin. 2016. The Viennese Students of Civilization: The Meaning and Context of Austrian Economics Reconsidered. Cambridge, MA: Cambridge University Press.

Hayek, Friedrich A. (1944) 2007. The Road to Serfdom. Edited by Bruce Caldwell. Chicago, IL: Chicago University Press.

Slobodian, Quinn. 2018. Globalists: The End of Empire and the Birth of Neoliberalism. Cambridge, MA: Cambridge University Press.

Wasserman, Janek. 2014. Black Vienna: The Radical Right in the Red City, 1918-1938. Ithaca, NY: Cornell University Press. 
Ola Innset holds a $\mathrm{PhD}$ in history and civilization from the European University Institute. His most recent books are Reinventing Liberalism: The Politics, Philosophy and Economics of Early Neoliberalism (1920-1947) (Springer, 2020) and a Norwegian monograph on the market turn in Norwegian politics entitled Markedsvendingen: Nyliberalismens historie $i$ Norge (Fagbokforlaget, 2020).

Contact e-mail: <ola.innset@nb.no> 